\title{
Problems of Online Learning during the Covid-19 Pandemic
}

Problematika Pembelajaran Online di Masa Pandemi Covid-19

\begin{tabular}{l}
\hline Author \\
\hline Nicky Rosadi \\
Universitas Indraprasta PGRI \\
Jakarta \\
nicky.rosadi@unindra.ac.id
\end{tabular}

\section{Duconomics}

\section{Sci-meet}

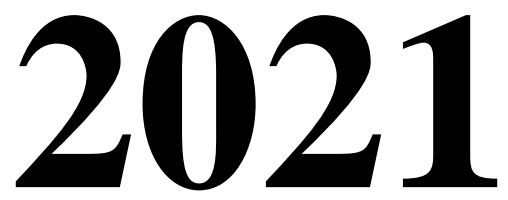

Page

\section{8-14}

DOI

Corresponding Author

081295499396

\begin{abstract}
This study aims to analyze the problems of online learning during the Covid19 pandemic. The methods used in this research are ex post facto and survey methods. The result is that online learning is not about what applications teachers use to teach their students. Teachers should not be busy debating which platform is better than another. However, teachers should realize that the most important thing is to apply teaching principles. Teaching is a process of making someone who doesn't know knows. The interaction between teachers and students is the key to conveying information. This information delivery room must be appropriate and easily accessible so that meetings between teachers and students can occur and give birth to neat and good interactions. In other words, a virtual study room must be highly accessible. In addition, the delivery of this interaction also needs to be arranged in such a way that students do not feel forced or forced to "eat" information from their teachers. Study time management needs to be applied in the implementation of online learning during this covid-19 pandemic. Based on the research conducted, it is known that interaction, accessibility, and time management really need to be considered in the application of online learning during the Covid-19 pandemic.
\end{abstract}

\begin{tabular}{l}
\hline Keywords \\
\hline online learning, Covid-19, principles of online teaching
\end{tabular}

online learning, Covid-19, principles of online teaching

Abstrak

Penelitian ini bertujuan untuk menganalisis problematika pembelajaran online di masa pandemi Covid-19. Medote yang digunakan dalam penelitian ini yaitu metode ex post facto dan survei. Hasil yang didapat yaitu, belajar secara daring bukanlah tentang aplikasi apa yang digunakan oleh pengajar untuk membelajarkan siswa-siswa mereka. Tidak semestinya para pengajar sibuk memperdebatkan platform yang satu lebih baik dari platform lainnya. Akan tetapi, seyogianya para pengajar menyadari bahwa terpenting adalah menerapkan prinsip-prinsip pengajaran. Mengajar adalah sebuah proses menjadikan seseorang yang tidak tahu menjadi tahu. Interaksi antara pengajar dan siswa menjadi kunci penyampaian informasi. Ruang penyampaian informasi ini haruslah layak dan mudah diakses agar pertemuan antara pengajar dan siswanya dapat terjadi dan melahirkan interaksi yang apik dan baik. Dengan kata lain, sebuah ruang belajar virtual mesti beraksesibilitas tinggi. Selain itu, penyampaian interaksi ini juga perlu diatur sedemikian rupa agar siswa tak merasa dipaksa atau terpaksa "memakan" informasi dari para pengajarnya. Manajemen waktu belajar perlu diterapkan dalam pelaksanaan pembelajaran daring di masa pandemi covid-19 ini. Berdasarkan penelitian yang dilakukan, diketahui bahwa interaksi, aksesibilitas, dan manajemen waktu sangat perlu diperhatikan dalam penerapan pembelajaran daring di masa pandemi Covid-19.

\begin{tabular}{l}
\hline Kata kunci \\
\hline pembelajaran online, Covid-19, prinsip pengajaran online
\end{tabular}




\section{PENDAHULUAN}

Pelaksanaan pendidikan yang biasa dilakukan secara tatap muka, tiba-tiba saja harus diakomodasi melalui dunia maya. Hal ini terjadi lantaran adanya protokol tetap penanganan Covid-19 yang mewabah di penjuru dunia. Indonesia terimbas. Pelaksanaan pendidikan melalui wadah dalam jaringan (daring), mau tidak mau, harus dilakukan. Sebagian lembaga mungkin tidak asing dengan pelaksanaan ini, namun, bagi beberapa lembaga yang masih asing dengan metode pembelajaran jarak jauh maupun daring ini jelas mengalami "kebingungan".

Pembelajaran yang dilakukan secara daring ini, menimbulkan pertanyaan besar, "Bagaimana sebenarnya pelaksanaan pembelajaran secara daring ini dilakukan? Apakah cukup dengan memberikan tugas? Atau perlu ada pendampingan hingga siswa memahami materi yang disampaikan?" Masalahnya adalah, paradigma pembelajaran daring yang dilakukan bisa jadi tidak sama antarpengajar di Indonesia.

Dalam pelaksanaan di lapangan, jika diklasifikasikan, terdapat tiga kecenderungan pola pengajaran jarak jauh yang terjadi belum lama ini. Pertama, pembelajaran yang dilakukan melalui bantuan aplikasi pengirim pesan obrolan. Pembelajaran biasanya diakomodasi melalui teks (textual based learning) yang dikirimkan ke aplikasi obrolan. Pengajar menyampaikan materi melalui perangkat yang disepakati, misalnya aplikasi WhatsApp, Telegram, dan sebagainya. Masalah yang muncul adalah, teks tidak dapat mengakomodasi mimik, gestur, dan intonasi. Maka tak heran, jika kadang terjadi kesalahan penafsiran dalam penerimaan informasi. Selain itu, manajemen waktu pelaksanaan pembelajaran pun menjadi tak terlihat. Karena teks ini bisa disampaikan dan dibaca kapan saja, maka respons yang muncul juga seolah tak terkendali waktunya. Baik pengajar maupun siswa, seolah berada pada kondisi belajar sepanjang waktu.

Kedua, terdapat pembelajaran yang dilakukan melalui bantuan aplikasi pertemuan virtual. Melalui aplikasi ini, pembelajaran bisa disampaikan secara luwes, seolah pengajar tengah menghadapi siswanya. Proses pembelajaran tatap muka seolah terjadi. Semua materi disampaikan dalam bentuk video (videomeet based learning). Banyak platform yang kini bermunculan untuk mengakomodasi kebutuhan ini. Mulai dari Zoom.us, Jit.si, YouTube Live, dan sebagainya. Pembelajaran terasa begitu interaktif. Guru menjelaskan, dan siswa dapat bertanya melalui fitur chat. Namun sayangnya, selain waktu yang terbatas, penggunaan video dalam aktivitas pembelajaran ini juga memakan kuota internet yang tidak sedikit. Memang, dalam praktiknya, manajemen waktu bisa terjadi. Semisal, pelajaran A dapat kita lakukan selama 1,5 jam dan dapat kita tutup saat sudah mencapai durasi itu. Namun akses yang diperlukan untuk mendapatkan pembelajaran itu, jelas perlu dipertimbangkan. Jika satu pelajaran saja sudah menghabiskan kuota internet 300-an megabyte, dalam sehari terdapat tiga pelajaran, maka siswa paling tidak memerlukan 1 gigabyte sehari untuk bisa mengikuti pembelajaran secara penuh. Mereka mungkin tidak "menjerit" habis di ongkos, tapi mereka "menjerit" di penggunaan kuota yang melejit. Belum lagi jika kita bicara masalah kualitas internet di satu daerah dengan daerah lain yang masih belum merata. Bisa jadi, aksesibilitas pembelajaran tersebut "terganggu".

Ketiga, beberapa pengajar mungkin sudah mampu mengaplikasikan penggunaan learning management system. Entah yang berupa Google Class Room atau Moodle. Setiap materi tinggal kita masukkan dan sampaikan melalui platform ini. Bisa berupa materi bacaan, presentasi, atau link video yang bisa diputar kapan saja. Siswa dapat mengaksesnya kapan saja tanpa mengganggu waktu istirahat pengajar. Independensi belajar sangat terlihat di sini. Namun sayangnya, akibat kemudahan ini, beberapa pengajar hanya mengunggah materi mereka begitu saja. Mereka merasa materi yang disampaikan dapat dipahami secara merata oleh siswasiswanya. Padahal, pemahaman tiap siswa jelas berbeda. Ada beberapa siswa yang perlu 


\section{$10 \begin{aligned} & \text { Dudonomics Sci-meet (Education and Economics Science Meet) } 2021 \\ & \text { Merdeka Belajar dan Tantangan Ekonomi dalam Menyongsong Era Society } 5.0\end{aligned}$}

pendampingan dalam memahami materi yang disampaikan. Di sini, interaksi antara pengajar dan siswanya seolah tak terjadi.

Berdasarkan fenomena tersebut, semestinya disadari bahwa kegiatan pembelajaran via daring tak ubahnya pembelajaran tatap muka yang biasa dilakukan. Bukan tentang di mana proses belajar terjadi, namun tentang bagaimana proses belajar semestinya terjadi. Ruang belajar yang semula terjadi secara nyata, kini kita pindahkan ke ruang virtual hingga terbentuklah ruang belajar virtual. Untuk itu, penulis akan membahas problematika pengajar dalam penerapan pembelajaran daring di masa pandemi covid-19.

\section{METODE}

Penelitian ini menggunakan metode ex post facto. Penelitian ex post facto merupakan metode yang banyak dipakai dan merupakan metode yang berguna yang dapat memberikan banyak informasi berharga bagi pengambilan keputusan di bidang pendidikan. Istilah ex post facto menunjukkan bahwa perubahan telah terjadi dan peneliti dihadapkan kepada masalah bagaimana menetapkan sebab dari akibat yang sedang diamati. Penelitian ex post facto meneliti hubungan sebab-akibat yang tidak dimanipulasi atau tidak diberi perlakuan oleh peneliti. Penelitian sebab-akibat dilakukan terhadap program, kegiatan, atau kejadian yang telah berlangsung atau telah terjadi. Adanya hubungan sebab-akibat didasarkan atas kajian teoretis, bahwa sesuatu variabel disebabkan atau dilatarbelakangi oleh variabel tertentu atau mengakibatkan variabel tertentu (Sappaile, 2010).

Data diambil dengan metode survei melalui penyebaran kuesioner dalam bentuk online yang disebar kepada mahasiswa Universitas Indraprasta PGRI, Jakarta. Dari survei tersebut, terkumpul sejumlah 282 mahasiswa yang mengikuti pembelajaran online dalam kurun waktu Maret hingga Juli 2020. Data diambil dengan mengklasifikasikan pengalaman belajar mereka berdasarkan textual based (aplikasi obrolan daring), videomeet based (pertemuan tatap muka daring), learning management system (sistem manajemen pembelajaran daring). Dari klasifikasi tersebut, diambillah data kendala yang mereka alami dari masing-masing proses pembelajaran.

\section{HASIL DAN PEMBAHASAN}

\section{Hasil}

Berdasarkan penelitian yang dilakukan, maka didapatkan data kendala yang dirasakan mahasiswa saat melakukan pembelajaran melalui aplikasi obrolan sebagai berikut.

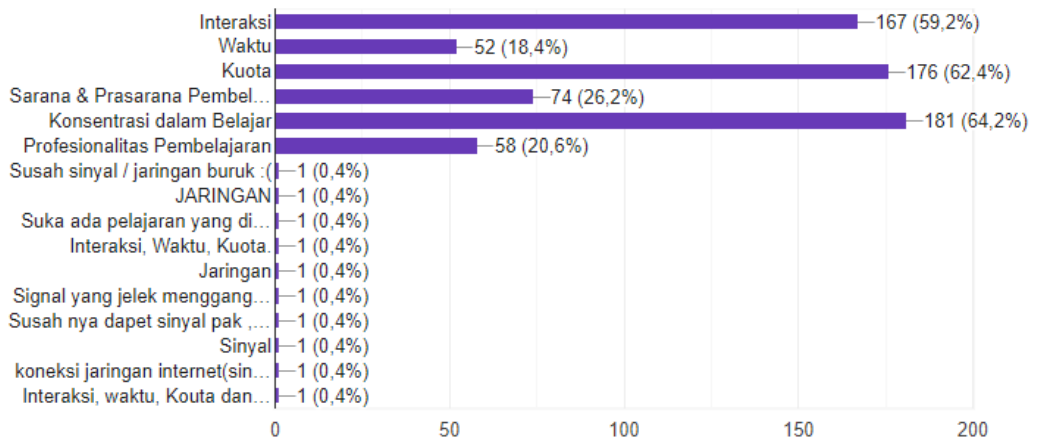


Duconomics Sci-meet Vol. 1

Juli, 2021

https://www.doi.org/10.xx

Gambar 1. Diagram rekapitulasi kendala yang dirasakan mahasiswa saat melakukan pembelajaran melalui aplikasi obrolan

Berdasarkan rekapitulasi tersebut, diketahui bahwa konsentrasi dalam belajar menjadi kendala paling banyak dialami oleh mahasiswa dalam proses pembelajaran melalui aplikasi obrolan online, yaitu sebanyak $64,2 \%$. Kendala kedua yaitu pada kuota, sebesar $62,4 \%$. Kemudian kendala tertinggi ketiga yaitu ada pada interaksi, yaitu 59,2\%.

Selanjutnya, berikut adalah data kendala yang dirasakan mahasiswa saat melakukan pembelajaran melalui aplikasi pertemuan tatap muka daring.

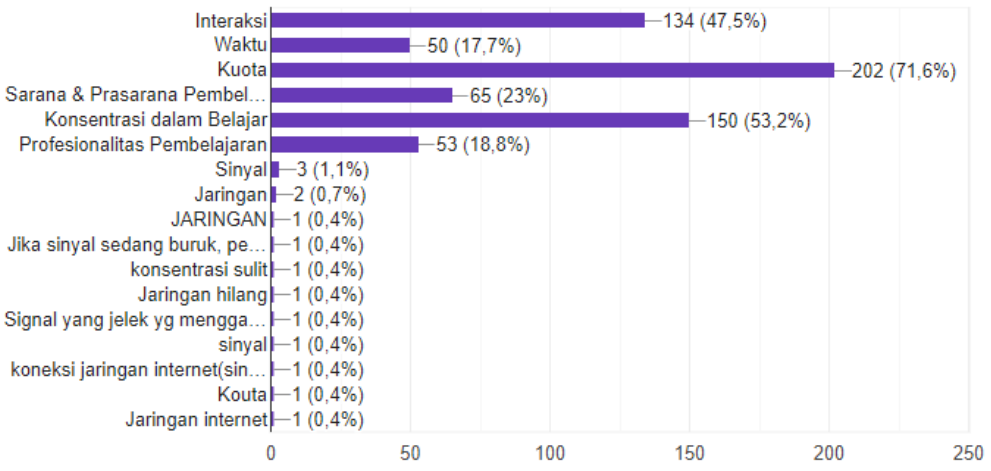

Sumber: Diolah (2021)

Gambar 2. Diagram rekapitulasi kendala yang dirasakan mahasiswa saat melakukan pembelajaran melalui aplikasi pertemuan tatap muka daring

Berdasarkan rekapitulasi tersebut, diketahui bahwa kuota menjadi kendala paling banyak dialami oleh mahasiswa dalam proses pembelajaran melalui aplikasi pertemuan tatap muka daring, yaitu sebanyak 71,6\%. Kendala kedua yaitu pada konsentrasi belajar, sebesar $53,2 \%$. Kemudian kendala tertinggi ketiga yaitu ada pada interaksi, yaitu 47,5\%.

Kemudian, berikut adalah data kendala yang dirasakan mahasiswa saat melakukan pembelajaran melalui learning management system.

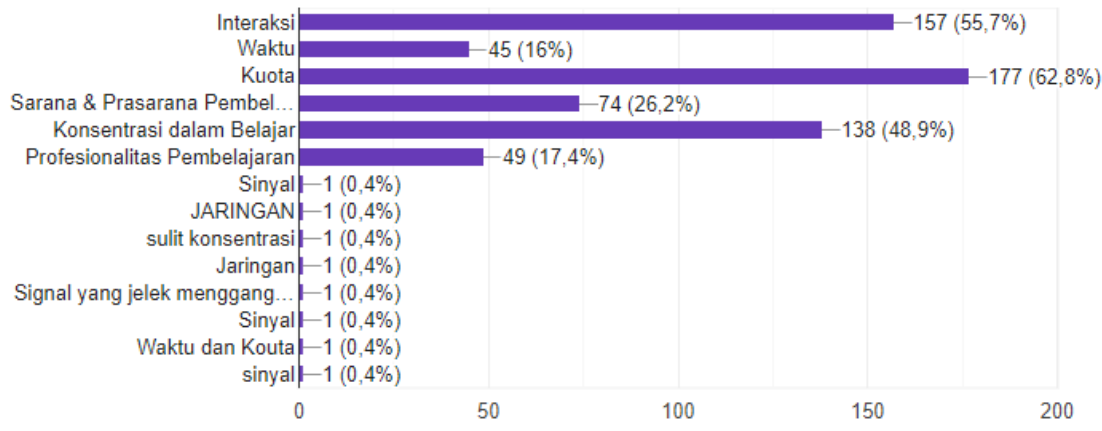

Sumber: Diolah (2021)

Gambar 3. Diagram rekapitulasi kendala yang dirasakan mahasiswa saat melakukan pembelajaran melalui learning management system

Berdasarkan rekapitulasi tersebut, diketahui bahwa kuota menjadi kendala paling banyak dialami oleh mahasiswa dalam proses pembelajaran melalui learning management system, yaitu sebanyak 62,8\%. Kendala kedua yaitu pada interaksi, sebesar 55,7\%. Kemudian kendala tertinggi ketiga yaitu ada pada konsentrasi belajar, yaitu 48,9\%.

Berdasarkan data yang diperoleh di atas, maka dapat terlihat permasalahan yang terjadi selalu pada interaksi, konsentrasi belajar, dan kuota. Adapun permasalahan lain yang muncul yaitu waktu, sarana dan prasarana pembelajaran, profesionalitas pembelajaaran, serta gangguan sinyal dan jaringan. Jika diklasifikasikan lagi, kuota, sinyal, jaringan, sarana dan prasarana 


\section{Dudonomics Sci-meet (Education and Economics Science Meet) 2021
Merdeka Belajar dan Tantangan Ekonomi dalam Menyongsong Era Society 5.0}

pembelajaran (perangkat) merupakan hal-hal yang digunakan untuk mengakses pembelajaran tersebut. Dengan demikian, jika hal-hal itu terkendala, maka mahasiswa tidak dapat mengakses pembelajaran yang diadakan. Oleh karena itu, hal-hal tersebut, akan dikelompokkan sebagai kendala aksesibilitas.

Sedangkan waktu, profesionalitas pembelajaran, hingga konsentrasi belajar, berkaitan dengan bagaimana seorang pengajar mengolah dan mengatur pembelajaran tersebut. Pengaturan yang baik ini tentu saja akan menghasilkan konsentrasi belajar yang baik pula. Jika pengajar mampu menatur waktu pembelajarannya dengan baik, tentu saja profesionalismenya akan terlihat. Untuk itu, hal-hal yang berkaitan dengan profesionalisme pengajar tersebut, akan dikelompokkan sebagai kendala manajemen waktu. Berikut akan dibahas problematika tersebut dari sisi interaksi, aksesibilitas, dan manajemen waktu.

\section{Pembahasan}

Berdasarkan penelitian yang dilakukan, setidaknya ada tiga hal yang perlu diperhatikan dalam pelaksanaan pembelajaran daring. Ketiga hal tersebut yaitu interaksi, aksesibilitas, dan manajemen waktu. Berikut akan dibahas terkait hal-hal tersebut.

Interaksi

Sanjaya dan Rusdi (2012) menjelaskan bahwa interaksi sosial merupakan hubungan timbal balik, saling mempengaruhi dalam pikiran dan tindakan, serta tidak terlepas dari suatu hubungan yang terjadi antar individu, sosial, dan masyarakat dalam kehidupan sehari-hari. Kebutuhan untuk berinteraksi dengan orang lain selalu dimiliki oleh individu. Melalui interaksi inilah, berbagai macam kesulitan yang dialami dan dirasakan seseorang akan diketahui oleh orang lain.

Dalam pembelajaran, interaksi menjadi hal penting. Melalui interaksi ini, kita dapat memastikan siswa kita sudah memahami materi kita atau masih perlu penjelasan tambahan. Untuk itu, kita harus dapat memastikan interaksi dapat berjalan dengan baik. Aktifkan pesan obrolan yang memungkinkan untuk diakses saat pembelajaran berlangsung. Tanya jawab yang bersifat krusial dapat dilakukan saat jadwal materi disampaikan. Namun, tanya jawab yang bersifat memastikan dapat dilakukan kapan saja dengan memperhatikan prinsip kesopanan. Sebagai pengajar, kita tentu memiliki privasi waktu dan menjaga profesionalitas kita. Untuk itu, perlu diberi pemahaman kepada siswa kita terkait kapan waktu yang bisa kita sediakan untuk menjawab pertanyaan-pertanyaan mereka.

Pada pembelajaran individual, guru dapat memberikan forum obrolan. Forum obrolan diberikan saat siswa membutuhkan konsultasi materi tertentu. Hal tersebut sejalan dengan penelitian yang dilakukan oleh Salamaet dkk. (2019) bahwa dari kondisi riil yang dialami satuan pendidikan di antaranya keterbatasan waktu dan tempat, keterbatasan materi, sulitnya pembelajaran secara individual, serta kurangnya inovasi dapat dicapai dengan aplikasi pendukung yang dapat mengakomodasi kekurangan-kekurangan tersebut.

Aksesibilitas

Aksesibilitas menurut kamus tata ruang yaitu keadaan atau ketersediaan hubungan dari suatu tempat ke tempat lain. Ilmiajayanti \& Dewi (2015) menjelaskan aksesibilitas sebagai kemudahan mencapai suatu lokasi tertentu dilihat dari berbagai aspek. Jika dikaitkan dengan pembelajaran daring, maka lokasi yang tengah kita bicarakan ini yaitu ruang belajar virtual yang digunakan oleh seorang pengajar.

Sebuah tempat belajar yang baik, biasanya adalah tempat belajar yang dapat dijangkau dengan mudah. Kita memahami bahwa beberapa siswa kita mencapai ruang belajar dengan berjalan kaki, naik sepeda, menggunakan sepeda motor, atau kendaraan lainnya. Jelas ini tergantung dari mana mereka berasal. Ada yang jaraknya dekat, ada yang jauh. Ada yang berasal dari desa, ataupun kota. Sama halnya dengan siswa kita yang mengakses ruang belajar 
virtual. Kecepatan dan koneksi tiap provider yang digunakan oleh siswa kita, jelas berbeda. Kita mungkin bisa merekomendasikan provider yang terbaik, seperti halnya kita bisa berkata, "Pakai motor saja agar bisa cepat sampai." Atau, "Naik mobil saja biar tidak kehujanan." Namun tetap, ada beberapa pertimbangan yang siswa kita gunakan dalam memilih provider tersebut. Kita tidak bisa memaksa mereka.

Selain itu, penyebaran jaringan koneksi juga tidak merata. Meski mereka menggunakan provider yang sama, bisa jadi, koneksi yang mereka dapatkan akan berbeda. Hal ini terjadi karena kualitas jaringan provider tersebut berbeda di tiap titik lokasinya. Untuk itu, layaknya sistem zonasi yang mengukur jarak tiap siswa ke ruang belajar agar akses belajar menjadi mudah, seyogianya pengajar juga dapat memetakan bagaimana karakteristik siswa kita dalam memilih provider selulernya. Penggunaan teks dalam ruang belajar virtual mampu menekan penggunaan kuota siswa kita, namun bukan berarti menggunakan video menjadi "haram" hukumnya. Kita bisa menyematkan video, hanya saja, perlu pemakluman untuk mengakses video tersebut dengan memberikan jangka waktu akses yang lebih lama. Pastikan bahwa materi-materi yang ada di ruang belajar virtual kita dapat diakses dengan mudah oleh seluruh siswa kita.

Menurut Wahyuningsih, Rusli, \& Bintarti (2015), aksesibilitas bagi pembelajar daring mutlak diperlukan. Hal ini tidak hanya terkait pada materi yang dapat dengan mudah diakses oleh para siswa, namun juga konektivitas interaksi yang harus terjadi meski dalam pembelajaran daring. Selain dipahami dengan jelas di mana materi pembelajaran dapat diakses, juga perlu dijelaskan dengan gamblang bagaimana siswa dapat berinteraksi dengan pengajar secara efektif.

\section{Manajemen Waktu}

Nurhidayati (2016) menyebutkan, manajemen waktu belajar memiliki peranan besar dalam keberhasilan belajar siswa. Oleh karena itu, pemahaman manajemen waktu pada siswa, perlu untuk ditingkatkan. Meski kebebasan akses dalam pelaksanaan pembelajaran daring sangat mungkin terjadi. Namun, secara formal, manajemen waktu belajar perlu untuk diterapkan.

Belajar di dalam ruang kelas merupakan situasi formal. Ada aturan-aturan terkait pelaksaan pembelajaran di dalamnya. Mungkin kita tidak menyadarinya, namun selalu ada komponen pembuka-inti-penutup dalam pelaksanaannya. Begitu pula pelaksanaan pembelajaran dalam sebuah ruang belajar virtual. Peru juga diperhatikan komponen pembukainti-penutup ini. Komponen pembuka biasa kita lakukan untuk presensi, pengantar, atau pretest. Komponen inti adalah penyampaian materi inti pembelajaran yang bisa kita sampaikan melalui teks, ceramah, diskusi, dan semacamnya. Komponen penutup dalam pembelajaran biasa kita lakukan untuk memastikan peserta didik memahami apa yang telah kita sampaikan. Bentuknya bisa berupa tanya jawab, tugas, atau posttest.

Dalam sebuah pembelajaran, paling tidak pembagian komponen ini bisa kita terapkan. Sehingga, manajemen waktu pembelajaran menjadi jelas. Berapa lama waktu yang digunakan untuk pembuka, berapa lama waktu yang kita perlukan untuk menyampaikan materi inti, dan berapa lama waktu yang diperlukan untuk memberikan tugas (harian atau mingguan). Sari (2010) menyebut peranan manajemen waktu sangat diperlukan dalam kegiatan belajar, karena manajemen waktu merupakan salah satu faktor intern yang mempengaruhi belajar.

\section{PENUTUP}

Pada akhirnya, belajar secara daring bukanlah tentang aplikasi apa yang digunakan oleh pengajar untuk membelajarkan siswa-siswa mereka. Tidak semestinya para pengajar sibuk 


\section{Dudonomics Sci-meet (Education and Economics Science Meet) 2021

memperdebatkan platform yang satu lebih baik dari platform lainnya. Akan tetapi, seyogianya para pengajar menyadari bahwa terpenting adalah menerapkan prinsip-prinsip pengajaran. Mengajar adalah sebuah proses menjadikan seseorang yang tidak tahu menjadi tahu. Interaksi antara pengajar dan siswa menjadi kunci penyampaian informasi. Ruang penyampaian informasi ini haruslah layak dan mudah diakses agar pertemuan antara pengajar dan siswanya dapat terjadi dan melahirkan interaksi yang apik dan baik. Dengan kata lain, sebuah ruang belajar virtual mesti beraksesibilitas tinggi. Selain itu, penyampaian interaksi ini juga perlu diatur sedemikian rupa agar siswa tak merasa dipaksa atau terpaksa "memakan" informasi dari para pengajarnya. Manajemen waktu belajar perlu diterapkan dalam pelaksanaan pembelajaran daring di masa pandemi covid-19 ini. Untuk itu, interaksi, aksesibilitas, dan manajemen waktu sangat perlu diperhatikan dalam penerapan pembelajaran daring di masa pandemi Covid-19.

\section{DAFTAR PUSTAKA}

Ilmiajayanti, F., \& Dewi, D. I. K. (2015). Persepsi Pengguna Taman Tematik Kota Bandung Terhadap Aksesibilitas Dan Pemanfaatannya. Ruang, 1(1), 21-30.

Nurhidayati, D. D. (2016). Peningkatan pemahaman manajemen waktu melalui bimbingan kelompok dengan teknik problem solving pada siswa. Universitas Ahmad Dahlan, 5(1), $1-12$.

Robbani, H., Rosadi, N., \& Nurfitria, O. (2020). Creating a Learning Management System at the Smart Bangun Negeri Community Learning Activity Center. KANGMAS: Karya Ilmiah Pengabdian Masyarakat, 1(2), 75-78. https://doi.org/10.37010/kangmas.v1i2.52

Rosadi, N. (Juli, 2020). Siapkah Pengajar Indonesia Mengimplementasikan Pembelajaran di Ruang Belajar Virtual? Duniadosen.com. Diakses pada 30 Oktober 2020 pukul 17.13 WIB di https://www.duniadosen.com/siapkah-pengajar-indonesiamengimplementasikan-pembelajaran-di-ruang-belajar-virtual/

Sanjaya, A., \& Rusdi, I. (2012). Hubungan interaksi sosial dengan kesepian pada lansia. Sumatera Utara: Fakultas Keperawatan.

Sari, A. N. (2010). Hubungan Antara Manajemen Waktu Dengan Prokrastinasi Akademik pada Mahasiswa yang Berwirausaha (Doctoral dissertation, Universitas Muhammadiyah Surakarta).

Wahyuningsih, S. S., Rusli, Y., \& Bintarti, A. (2015). Aksesibilitas mahasiswa pada tutorial online program studi perpustakaan. Jurnal pendidikan terbuka dan jarak jauh, 16(1), 29-38. 